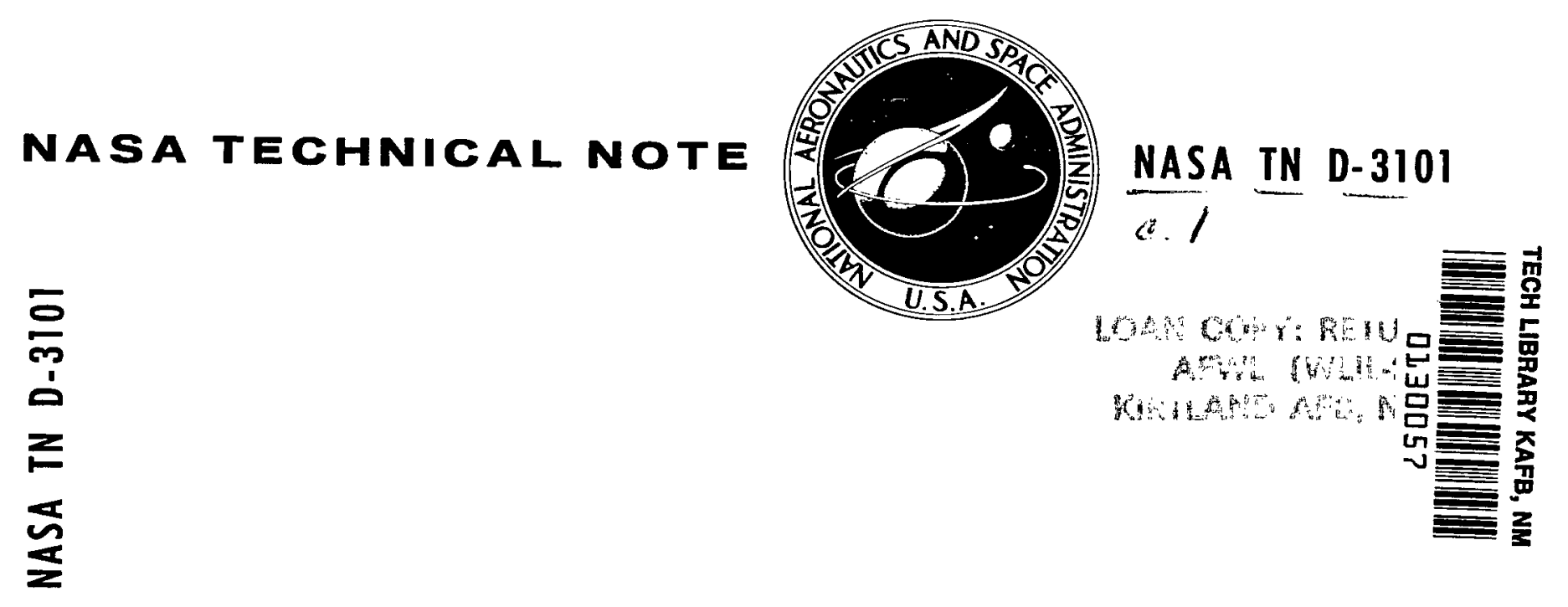

\title{
BEARING LIFE AND FAILURE \\ DISTRIBUTION AS AFFECTED \\ BY ACTUAL COMPONENT \\ DIFFERENTIAL HARDNESS
}

by Erwin V. Zaretsky, Richard J. Parker, William J. Anderson, and David W. Reichard

Lewis Research Center

Cleveland, Obio

NATIONAL AERONAUTICS AND SPACE ADMINISTRATION • WASHINGTON, D. C.

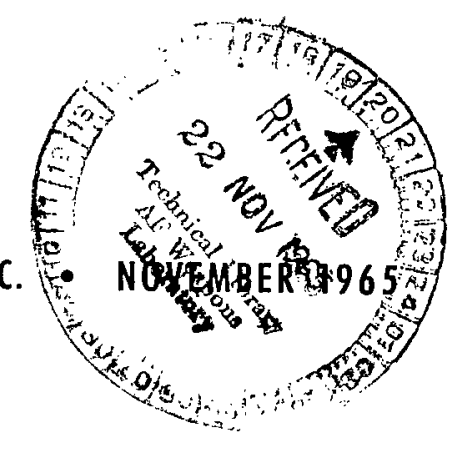


BEARING LIFE AND FAILURE DISTRIBUTION AS AFFECTED BY ACTUAL COMPONENT DIFFERENTIAL HARDNESS

By Erwin V. Zaretsky, Richard J. Parker, William J. Anderson, and David W. Reichard

Lewis Research Center

Cleveland, Ohio 


\title{
BEARING LIFE AND FAILURE DISTRIBUTION AS AFFECTED BY ACTUAL COMPONENT DIFFERENTIAL HARDNESS
}

\author{
by Erwin V. Zaretsky, Richard J. Parker, William J. Anderson, \\ and David W. Reichard
}

Lewis Research Center

\begin{abstract}
SUMMARY
Rolling-contact fatigue tests were performed on SAE 52100 207-size deep-groove ball bearings to deter mine the relation between bearing fatigue life and actual bearing component hardness differences and the effect of actual component hardness differences on bearing fatigue life scatter. The 207-size bearings with inner and outer races from the same heat of SAE 52100 material and with nominal Rockwell C hardnesses of 63 were assembled with SAE 52100 balls from the same heat of material tempered to nominal Rockwell $\mathrm{C}$ hardnesses of 60,63, 65, and 66. Test conditions included an inner race speed of 2750 rpm, a radial load of 1320 pounds, which produced maximum Hertz stresses of 352000 and 336000 psi at the inner and the outer races, respectively, and a highly purified naphthenic mineral oil as the lubricant.

Subsequent to testing, the bearings were disassembled, and all component hardnesses were measured. The bearings were regrouped according to their actual values of $\Delta \mathrm{H}$ for Rockwell $\mathrm{C}$ hardness increments of 0.5 and 1.0 , where $\Delta \mathrm{H}$ is the difference between the actual hardness of the rolling elements in the bearing and the actual hardness of the inner race. The fatigue life and scatter results were compared with component hardness combinations and data previously obtained from the five-ball fatigue tester. The following results were obtained:

The bearings exhibited a maximum life for a $\Delta H$ of approximately 1 to 2 points Rockwell C. These results correlated with those obtained with the five-ball fatigue tester. For actual $\Delta \mathrm{H}$ increments of 0.5 , the maximum life was obtained for a $\Delta \mathrm{H}$ of 1.5 to 2 points Rockwell $\mathrm{C}$ and is approximately four times the life for the nominal $\Delta \mathrm{H}$ of approximately 2 points Rockwell C. These results substantiate that maximum bearing fatigue life is obtained when the rolling elements are 1 to 2 points Rockwell $\mathrm{C}$ harder than the races.

For both the full-scale bearings and the five-ball system, fatigue scatter decreased with increasing $\Delta H$ until a minimum value was obtained at a value of $\Delta H$ of approximately 2 points Rockwell C. Beyond this value the fatigue life scatter increased.
\end{abstract}




\section{INTRODUCTION}

In aerospace applications high reliability is of paramount importance. Of almost equal importance is the economic consideration, where equipment downtime and maintenance must be minimized. A major factor affecting equipment reliability and operating costs is the life of the rolling-element bearings used in the equipment. Unfortunately, failure of these bearings due to fatigue is to be expected. The problem is, therefore, one of increasing bearing fatigue life.

Recent developments in bearing steel alloys has provided marked increases in rolling-element fatigue life and reliability. The development of new and improved alloys, however, has advanced the state of the art to the point where further major metallurgical improvements in bearing steels are not immediately anticipated. Research must therefore concentrate on improving the physical and metallurgical properties and mechanical applications of available bearing steels.

The five-ball fatigue tester was used to study the effect of component hardness combinations on the fatigue life of rolling elements subjected to repeated stresses applied in rolling contact (ref. 1). SAE 52100 steel balls from the same heat of material were tempered to a range of Rockwell $\mathrm{C}$ hardnesses from 60 to 66 . Groups of upper test balls with nominal Rockwell $\mathrm{C}$ hardnesses of 60,62 , and 65 were run against lower test balls of nominal hardnesses of $60,62,63,65$, and 66 . These results indicated that for a specific upper test ball hardness, the rolling contact fatigue life and load-carrying capacity of the test system increased with increasing lower test ball hardness to an intermediate hardness value, where a peak life was attained. For further increases in hardness of the lower test balls, system life and capacity decreased. The peak-life - hardness combination occurred for each of the three lots of upper test balls in which the hardness of the lower test ball was approximately 1 to 2 points Rockwell $\mathrm{C}$ greater than that of the upper test ball. According to these results for SAE 52100 steel, a maximum bearing fatigue life should occur when the balls of the bearing are 1 to 2 points harder than the races.

Differences in plastic deformation of the rolling surfaces and contact temperature for different hardness combinations could not account for measured differences in life.

Additional work reported in reference 2 indicates an interrelation among differences in component hardness, induced compressive residual stress, and fatigue life. Examination of the data in reference 1 also indicates that there may be some interrelation between the bearing fatigue life scatter, as indicated by the slope of a Weibull plot, and component hardnesses.

Tests of 207-size deep-groove ball bearings of SAE 52100 steel, which were run at a radial load of 1320 pounds (which produced maximum Hertz stresses of 352000 and $336000 \mathrm{psi}$ at the inner and the outer races, respectively) with a highly refined naphthenic mineral oil as the lubricant, are reported in reference 3 . These bearing races had a 
nominal Rockwell $\mathrm{C}$ hardness of 63 . The balls of the bearing were divided into four groups and were tempered to produce nominal Rockwell $\mathrm{C}$ hardnesses of 60, 63, 65, and 66 .

These tests indicated that maximum bearing fatigue life and load capacity are achieved when the rolling elements of a bearing are 1 to 2 points Rockwell $\mathrm{C}$ harder than the races. As a result of heat-treating irregularities, however, most bearings manufactured have a variation in component hardness of \pm 2 points Rockwell $\mathrm{C}$ for the races and \pm 1 point Rockwell $\mathrm{C}$ for the rolling elements, that is, balls and rollers. This would indicate as an example, that where there are intentions of making a bearing having balls and races of equal hardness, there is a probability of having a $\Delta \mathbf{H}$ of \pm 3 Rockwell $\mathrm{C}$. The objectives of the research reported herein were, therefore, to determine (1) the relation between bearing fatigue life and actual bearing component hardness differences and (2) the effect of actual component hardness differences on bearing fatigue life scatter.

In order to accomplish these objectives, the 207-size bearings tested under the conditions reported in reference 3 were disassembled, and all component hardnesses were measured. The bearings were regrouped according to their actual values of $\Delta H$ for Rockwell $\mathrm{C}$ hardness increments of 0.5 and 1.0 , where $\Delta \mathrm{H}$ is the difference between the actual hardness of the rolling elements in the bearing and the actual hardness of the inner race. The data were reanalyzed, and fatigue life and scatter results were compared with component hardness combinations and data obtained in the five-ball fatigue tester as reported in reference 1 .

\section{SPECIMENS AND PROCEDURE}

Fatigue tests were conducted with 207-size radial ball bearings. The dimensions of the bearing were as follows:

\begin{tabular}{|l|r|} 
Track diameter, in. & \\
Inner race & 1.6648 \\
Outer race & 2.5411 \\
Number of balls & 9 \\
Ball diameter, in. & 0.4375 \\
Conformity, percent & 51 \\
Inner race & 52 \\
Outer race & \\
\hline
\end{tabular}

The inner and the outer races were manufactured from the same heat of air-melted SAE 52100 steel and heat treated as follows: 
(1) The races were austenitized at $1500^{\circ} \mathrm{F}$ for 20 minutes, $1530^{\circ} \mathrm{F}$ for 20 minutes, $1540^{\circ} \mathrm{F}$ for 20 minutes, and then oil quenched.

(2) The inner races were tempered at $320^{\circ} \mathrm{F}$ for one hour, air cooled, and then given a second temper at $330^{\circ} \mathrm{F}$ for 30 minutes.

(3) The outer races were tempered at $320^{\circ} \mathrm{F}$ for one hour, air cooled, and then given a second temper at $320^{\circ} \mathrm{F}$ for 30 minutes.

(4) The final nominal hardness of the inner and outer races was Rockwell C 63.

All the balls for the bearings were made from one heat of air-melted SAE 52100 steel and heat treated as follows:

TABLE I. - BALL TEMPERING SCHEDULE

FOR SAE 52100 STEEL BALLS RUN

IN 207-SIZE BEARINGS

[Ball diameter, 0.4375 in.; duration of each temper, $1 \mathrm{hr}$.]

\begin{tabular}{|c|c|c|}
\hline \multirow{2}{*}{$\begin{array}{c}\text { Nominal } \\
\text { Rockwell C } \\
\text { hardness }\end{array}$} & \multicolumn{2}{|c|}{ Temperature, ${ }^{\circ} F$} \\
\hline & $\begin{array}{l}\text { First } \\
\text { temper }\end{array}$ & $\begin{array}{l}\text { Second } \\
\text { temper }\end{array}$ \\
\hline 60 & 250 & 435 \\
\hline 63 & 250 & 330 \\
\hline 65 & 250 & 260 \\
\hline 66 & 200 & None \\
\hline
\end{tabular}

The balls were stabilized at $1250^{\circ} \mathrm{F}$ for 40 minutes, austenitized at $1500^{\circ} \mathrm{F}$ for $30 \mathrm{~min}-$ utes, and then oil quenched. The as-quenched hardness of the balls was approximately 66.5 Rockwell C. The balls were then tempered according to the schedule shown in table I.

The balls and the races were finished to an AFBMA 10 and an ABEC 5 specification, respectively. The bearings were assembled into four groups based on ball nominal Rockwell $\mathrm{C}$ hardnesses of $60,63,65$, and 66 . The bearings were tested at ambient temperature, at an inner-race speed of $2750 \mathrm{rpm}$, at a radial load of 1320 pounds, and with a highly purified naphthenic mineral oil as the lubricant.

At the conclusion of tests under these conditions, the bearings were disassembled. Parallel flats approximately $1 / 8$ inch in diameter were ground on two balls of each bearing randomly selected to facilitate eight hardness measurements (four per ball). Four measurements were taken at regularly spaced locations on each of the bearing races. The values of these measurements were averaged and used to represent the actual hardness of each component. These average values were used to determine the actual $\Delta H$ values (actual hardness of the balls minus the actual hardness of the inner race) as distinguished from the nominal $\Delta \mathrm{H}$ values in table II for each of the bearings. The four groups of bearings were then segregated according to tables $I I$ and IV, respectively.

Total running time for each bearing was recorded in number of inner-race revolutions. The statistical methods outlined in reference 4 were used to obtain a plot of the $\log \log$ of the reciprocal of the probability of survival as a function of the log of stress cycles to failure (Weibull coordinates). 
TABLE I. - BEARING FATIGUE LIFE WITH VARYING BALL HARDNESS

FOR 207-SIZE DEEP-GROOVE BALL BEARINGS

[Radial load, 1320 lb; speed, 2750 rpm; race nominal Rockwell C hardness, 63. ]

\begin{tabular}{|c|c|c|c|c|c|}
$\begin{array}{c}\text { Nominal } \\
\text { ball } \\
\text { Rockwell C } \\
\text { hardness }\end{array}$ & $\begin{array}{c}\text { Nominal } \Delta \mathrm{H} \\
\text { (difference } \\
\text { in hardness } \\
\text { between } \\
\text { balls and } \\
\text { race) }\end{array}$ & $\begin{array}{c}\text { 10-Percent } \\
\text { fatigue life, } \\
\text { millions of } \\
\text { inner-race } \\
\text { revolutions }\end{array}$ & $\begin{array}{c}\text { Bearing load } \\
\text { capacity } \\
\text { based on } \\
\text { experimental } \\
\text { life, } \\
\mathrm{C}\end{array}$ & $\begin{array}{c}\text { Confidence } \\
\text { number, } \\
\text { percent }^{\mathrm{a}}\end{array}$ & $\begin{array}{c}\text { Failure index } \\
\text { (number of } \\
\text { bearings failed } \\
\text { out of number } \\
\text { of bearings } \\
\text { tested) }\end{array}$ \\
60 & -3 & 21 & 3640 & 89 & 14 out of 28 \\
63 & 0 & 77 & 5620 & 60 & 11 out of 25 \\
65 & 2 & 106 & 6250 & -- & 12 out of 28 \\
66 & 3 & 74 & 5540 & 62 & 14 out of 27 \\
\hline
\end{tabular}

${ }^{a}$ Percentage of time that 10-percent life obtained with each hardness combination will have same relation to hardness combination in that series exhibiting highest 10 -percent life.

TABLE III. - BEARING FATIGUE LIFE WITH VARYING BALL HARDNESS

FOR 207-SIZE DEEP-GROOVE BALL BEARINGS WITH ACTUAL

ROCKWELL C HARDNESS INCREMENT OF 0.5

[Radial load, $1320 \mathrm{lb}$; speed, $2750 \mathrm{rpm}$.

\begin{tabular}{|c|c|c|c|c|c|}
\hline $\begin{array}{l}\text { Actual } \Delta \mathrm{H} \\
\text { (ball Rockwell } \mathrm{C} \\
\text { hardness minus }\end{array}$ & $\begin{array}{l}\text { Weibull } \\
\text { slope }\end{array}$ & \multicolumn{2}{|c|}{$\begin{array}{c}\text { Fatigue life, millions } \\
\text { of inner-race } \\
\text { revolutions }\end{array}$} & $\begin{array}{c}\text { Ratio of } \\
50 \text {-percent } \\
\text { life to }\end{array}$ & $\begin{array}{l}\text { Failure index (number } \\
\text { of bearings failed out } \\
\text { of number of bearings }\end{array}$ \\
\hline $\begin{array}{c}\text { Rockwell C } \\
\text { hardness) }\end{array}$ & & $\begin{array}{c}\text { 10-Percent } \\
\text { life }\end{array}$ & $\mid \begin{array}{c}50-\text { Percent } \\
\text { life }\end{array}$ & $\begin{array}{c}10 \text {-percent } \\
\text { life }\end{array}$ & \\
\hline-1.5 to -1.0 & 0.9 & 9.0 & 72.0 & 8.0 & 8 out of 15 \\
\hline-1.0 to -0.5 & 1. 1 & 34.0 & 200.0 & 5.9 & 3 out of 8 \\
\hline 0.5 to 1.0 & 1.0 & 15.5 & 106.0 & 6.9 & 3 out of 3 \\
\hline 1.0 to 1.5 & 1. 1 & 70.0 & 365.0 & 5.2 & 7 out of 14 \\
\hline 1.5 to 2.0 & $a_{1.7}$ & 405.0 & 1220.0 & 3.0 & 1 out of 8 \\
\hline 2.0 to 2.5 & 1.8 & 92.0 & 265.0 & 2. 9 & 9 out of 11 \\
\hline 2.5 to 3.0 & 1.4 & 78.0 & 295.0 & 3.8 & 10 out of 17 \\
\hline 3.0 to 3.5 & 1.1 & 82.0 & 505.0 & 6.2 & 7 out of 22 \\
\hline 3.5 to 4.0 & $\mathrm{~b}_{1.0}$ & 22.0 & 136.0 & 6.1 & 2 out of 5 \\
\hline
\end{tabular}

${ }^{\mathrm{a}}$ Slope value assumed to be that of $\Delta \mathrm{H}$ between 1.5 and 2.5.

${ }^{b}$ Slope value assumed to be that of $\Delta H$ between 3.0 and 4.0 . 
TABLE IV. - BEARING FATIGUE LIFE WITH VARYING BALL HARDNESS

FOR 207-SIZE DEEP-GROOVE BALL BEARINGS WITH ACTUAL

ROCKWELL C HARDNESS INCREMENT OF 1.0

[Radial load, $1320 \mathrm{lb}$; speed, $2750 \mathrm{rpm}$.

\begin{tabular}{|c|c|c|c|c|c|}
\hline \multirow{2}{*}{$\begin{array}{c}\text { Actual } \Delta H \\
\text { (ball Rockwell C } \\
\text { hardness minus } \\
\text { inner-race } \\
\text { Rockwell C } \\
\text { hardness) }\end{array}$} & \multirow[t]{2}{*}{$\begin{array}{l}\text { Weibull } \\
\text { slope }\end{array}$} & \multicolumn{2}{|c|}{$\begin{array}{c}\text { Fatigue life, millions } \\
\text { of inner-race } \\
\text { revolutions }\end{array}$} & \multirow{2}{*}{$\begin{array}{c}\text { Ratio of } \\
50 \text {-percent } \\
\text { life to } \\
\text { 10-percent } \\
\text { life }\end{array}$} & \multirow{2}{*}{$\begin{array}{l}\text { Failure index (number } \\
\text { of bearings failed out } \\
\text { of number of bearings } \\
\text { tested) }\end{array}$} \\
\hline & & $\begin{array}{c}\text { 10-Percent } \\
\text { life }\end{array}$ & $\begin{array}{c}\text { 50-Percent } \\
\text { life }\end{array}$ & & \\
\hline-2.0 to -1.0 & 0.9 & 8.0 & 64.5 & 8.1 & 9 out of 16 \\
\hline-1.0 to 0 & 1.0 & 24.8 & 178.0 & 7.2 & 6 out of 11 \\
\hline 0 to 1.0 & 1.0 & 15.2 & 106.0 & 7.0 & 3 out of 3 \\
\hline 0.5 to 1.5 & 1. 6 & 53.0 & 290.0 & 5.7 & 10 out of 17 \\
\hline 1.0 to 2.0 & 1.1 & 108.0 & 605.0 & 5.5 & 8 out of 22 \\
\hline 1.5 to 2.5 & 1. 7 & 129.0 & 400.0 & 3.1 & 10 out of 19 \\
\hline 2.0 to 3.0 & 1.7 & 90.0 & 276.0 & 3.1 & 19 out of 28 \\
\hline 2.5 to 3.5 & 1.3 & 84.0 & 350.0 & 4. 2 & 17 out of 39 \\
\hline 3.0 to 4.0 & 1.0 & 64.5 & 435.0 & 6.8 & 9 out of 27 \\
\hline
\end{tabular}

\section{RESULTS AND DISCUSSION}

\section{Fatigue Results}

Results of the fatigue tests of the four groups of bearings with races of nominal Rockwell $\mathrm{C}$ hardness 63 and balls of nominal Rockwell $\mathrm{C}$ hardnesses of 60, 63, 65, and 66 (ref. 3) are presented in figure 1 and summarized in table II.

The 10-percent life (life in which 90 percent of the specimens will survive) was used for comparitive purposes. The confidence numbers for the 10-percent lives were calculated and are also given in table II. These confidence numbers indicate the percentage of the time that the 10-percent life obtained with each hardness combination will have the same relation to the hardness combination exhibiting the highest 10-percent life. Thus, a confidence number of 90 means that 90 out of 100 times the specimens tested with a given hardness combination will give a life relation similar to those presented. The failure index given in table II indicates the number of failures out of the number of bearing specimens tested.

The relative bearing 10-percent lives (data from table II) are plotted as a function of $\Delta \mathrm{H}$, the difference in hardness between the balls and the races, in figure 2. A maximum life exists where $\Delta \mathrm{H}$ is between 1 and 2 points Rockwell $\mathrm{C}$. 


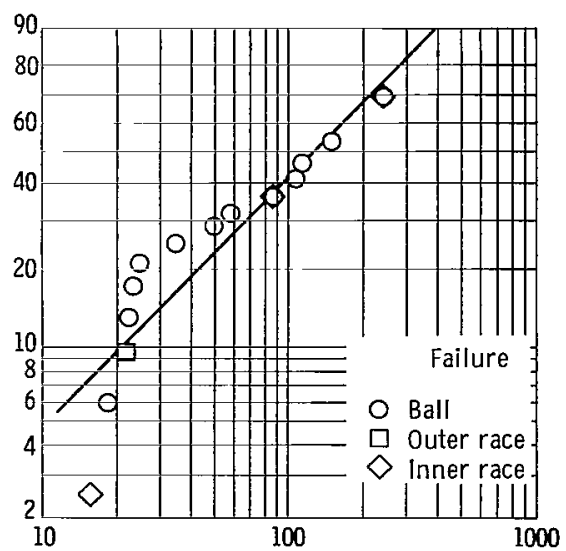

(a) Ball Rockwell $\mathrm{C}$ hardness, 60.

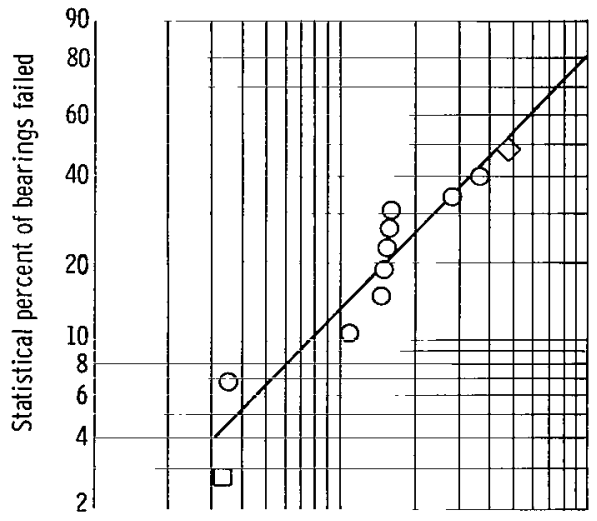

(b) Ball Rockwell C hardness, 63.

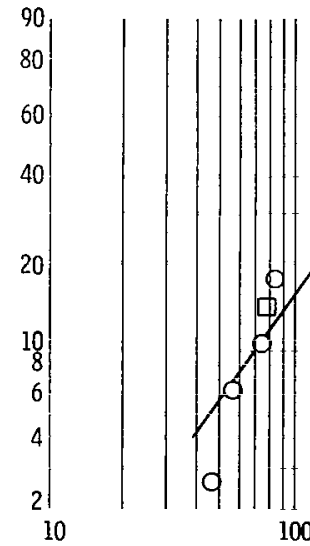

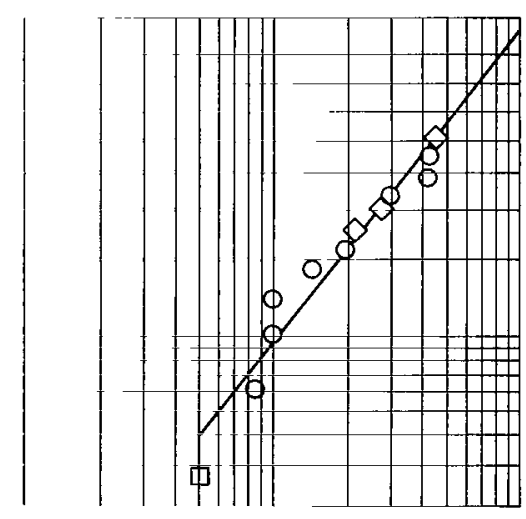

(c) Ball Rockwell C hardness, 65.

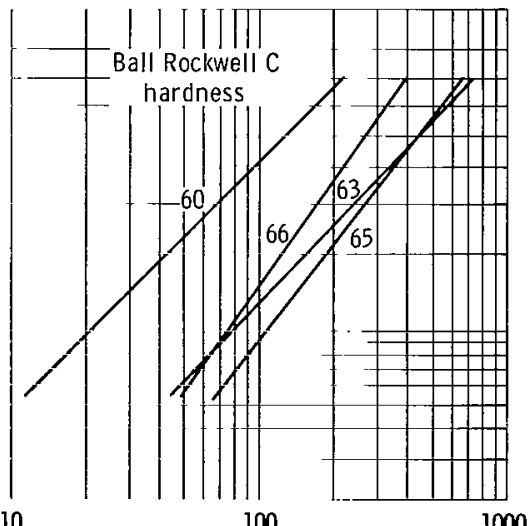

100

1000

(d) Ball Rockwell C hardness, 66.

(e) Summary of fatigue lives.

Figure 1. - Rolling-contact fatigue life of 207-size deep-groove ball bearings with SAE 52100 races of nominal Rockwell $C$ hardness of 63 and SAE 52100 balls of varying hardness. Radial load, 1320 pounds; speed, $2750 \mathrm{rpm}$; no heat added. 


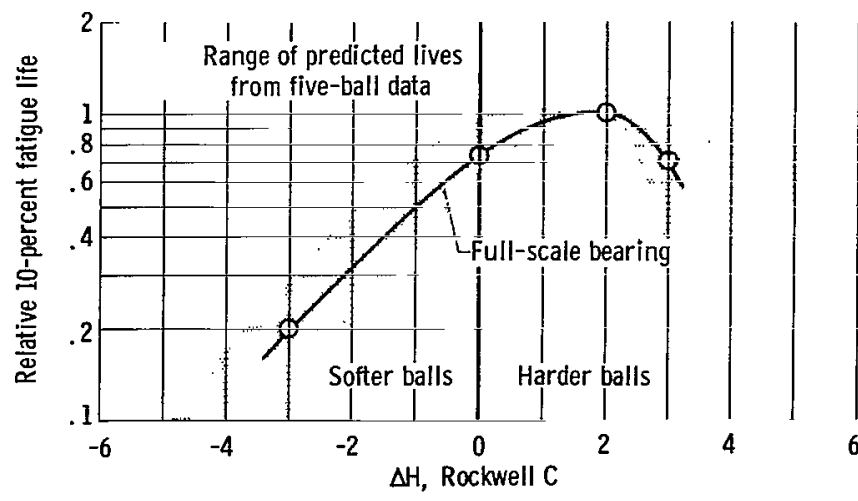

Figure 2. - Relative 10-percent life as function of $\Delta H$ (difference in Rockwell $\mathrm{C}$ hardness between balls and races) for 207-size deepgroove ball bearings with SAE 52100 races of nominal Rockwell $C$ hardness 63 and SAE 52100 balls of varying hardnesses. Radial load, 1320 pounds; speed, $2750 \mathrm{rpm}$; no heat added.
An important criterion of bearing operation is the load-carrying capacity. This capacity is the load that the bearing can sustain for 1 million inner-race revolutions with a 90-percent probability of survival. The load-carrying capacity of each of the bearings tested may be calculated from the fatigue data results summarized in table $\Pi$ (p. 5) by use of the following equation:

$$
C=P \sqrt[3]{L}
$$

where

\section{C load capacity, lb}

$\mathrm{P}$ load on bearing, $1 \mathrm{~b}$

L 10-percent life, millions of inner-race revolutions

The calculated capacities for the bearings are given in table $\Pi$. As with the fatigue results, a maximum capacity exists at a value of $\Delta \mathrm{H}$ of 1 to 2 points Rockwell $\mathrm{C}$.

The five-ball fatigue data from reference 1 , obtained under test conditions similar to those for the bearings but at a maximum Hertz stress of 800000 psi are summarized in table V. These five-ball system 10-percent lives are plotted as a function of the bearing 10-percent lives in figure 3 for the same hardness combinations, that is, upper-ball (inner-race) hardness of 63 Rockwell $\mathrm{C}$ and lower-ball (rolling-element) nominal hardnesses of $60,63,65$, and 66 Rockwell $\mathrm{C}$. These data indicate a correlation between the five-ball system and full-scale bearings, even though the five-ball-system data were obtained at a higher Hertz stress. From the five-ball data (table V) a range of relative five-ball-system lives are presented as the shaded area in figure 2. As was expected, the relative 10-percent fatigue lives of the bearings fell within the relative life range of the five-ball system for equivalent values of $\Delta \mathrm{H}$.

\section{Effect of Component Hardness Quality Control on Fatigue Life and Scatter}

As a result of heat-treating irregularities, most bearings manufactured, in general, have a variation in component hardness of \pm 2 Rockwell $\mathrm{C}$ for races and \pm 1 Rockwell $\mathrm{C}$ for rolling elements, that is, for balls and rollers. This variation would indicate that where there is an intention of making a bearing with balls and races of equal hardness, there is 
TABLE V. - SYSTEM FATIGUE LIFE AND LOAD CAPACITY

OBTAINED WITH VARYING HARDNESS COMBINATIONS

IN FIVE-BALL FATIGUE TESTER

[Initial maximum Hertz stress, $800000 \mathrm{psi}$; system thrust load, $340 \mathrm{lb}$; contact angle, $30^{\circ}$; room temperature; material, SAE 52100 steel; data from ref. 1.]

\begin{tabular}{|c|c|c|c|c|}
\hline $\begin{array}{c}\text { Upper test } \\
\text { ball } \\
\text { Rockwell C } \\
\text { hardness }\end{array}$ & $\begin{array}{c}\text { Lower test } \\
\text { ball } \\
\text { Rockwell C } \\
\text { hardness }\end{array}$ & $\begin{array}{c}\text { Difference in } \\
\text { Rockwell C } \\
\text { hardness } \\
\text { between } \\
\text { lower and } \\
\text { upper test } \\
\text { balls, } \\
\Delta \mathrm{H}\end{array}$ & $\begin{array}{l}\text { 10-Percent } \\
\text { fatigue life, } \\
\text { millions of } \\
\text { upper-ball } \\
\text { revolutions }\end{array}$ & $\begin{array}{l}\text { Weibull } \\
\text { slope }\end{array}$ \\
\hline \multirow[t]{5}{*}{60.5} & 60.5 & 0 & 2. 1 & 0.9 \\
\hline & 61.9 & 1.4 & 5.8 & 1. 4 \\
\hline & 63.2 & 2.7 & 2.7 & .8 \\
\hline & 65.2 & 4. 7 & 3.2 & .8 \\
\hline & 66.4 & 5.9 & 3.3 & 1.0 \\
\hline \multirow[t]{5}{*}{63.2} & 59.7 & -3.5 & 0.4 & 0.9 \\
\hline & 61.8 & -1.4 & 1.4 & 1.1 \\
\hline & 63.4 & .2 & 2.6 & 1. 1 \\
\hline & 65.0 & 1.8 & 4. 7 & 1.3 \\
\hline & 66.2 & 3.0 & 1. 2 & .8 \\
\hline \multirow[t]{5}{*}{65.2} & 60.5 & -4.7 & 0.6 & 0.8 \\
\hline & 61.9 & -3.3 & 1.2 & 1.2 \\
\hline & 63.2 & -2.0 & 1.7 & 1.1 \\
\hline & 65.2 & 0 & 3.9 & 1.2 \\
\hline & 66.4 & 1.2 & 5.7 & 1.3 \\
\hline
\end{tabular}

a probability of having a $\Delta H$ of \pm 3 Rockwell $C$. From the data presented in table $\Pi$, a $\Delta \mathrm{H}$ of -3 points Rockwell $\mathrm{C}$ can account for more than a 70 percent reduction in fatigue life when compared with a $\Delta \mathrm{H}$ of 0 . It was therefore theorized that if the value of $\Delta H$ in any particular group of bearings were closely controlled, bearing fatigue life scatter would decrease. It was further theorized that the life of a bearing with a closely controlled value of $\Delta \mathrm{H}$ would greatly exceed the maximum life indicated by the bearing data presented in figure 1 (p. 7) and table II (p. 5). Therefore, to determine the effect of quality control on bearing fatigue life as a function of $\Delta \mathrm{H}$ and to determine whether the variation in component hardness can affect bearing fatigue life scatter, each of the 207-size bearings was disassembled, and each component was measured as previously discussed. 


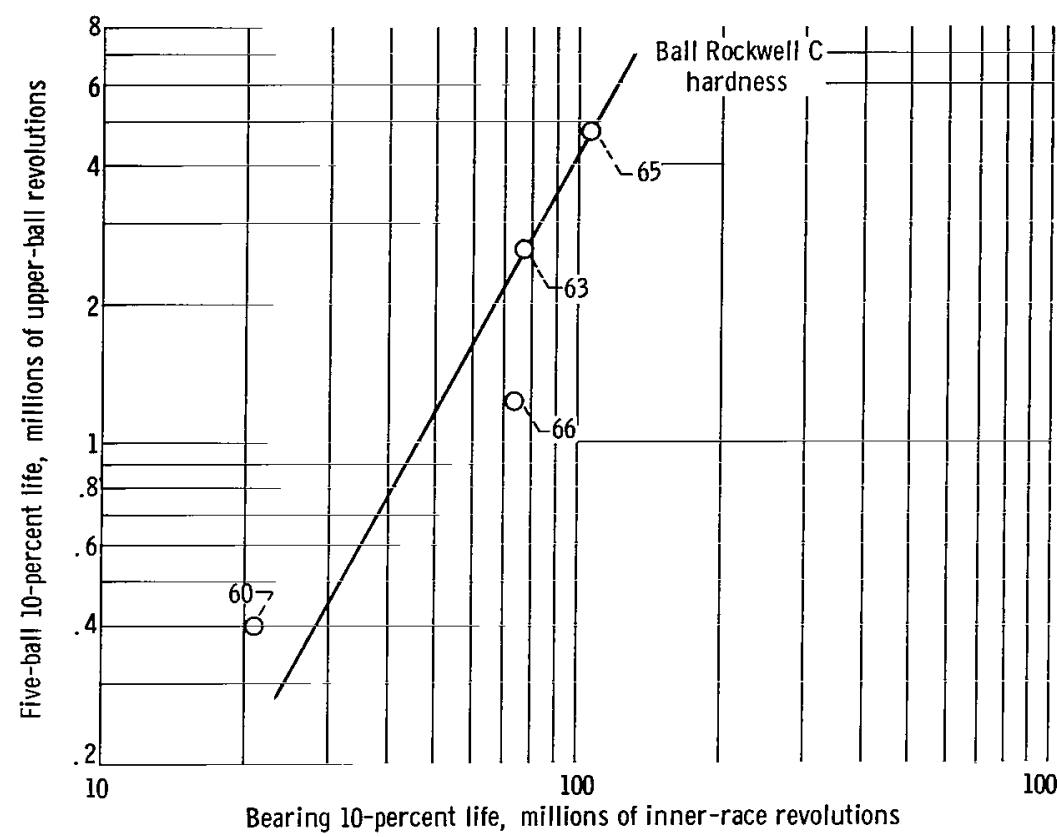

Figure 3. - Ten-percent life of five-ball fatigue system as function of 10-percent life of 207-size bearings. Inner race and upper test ball Rockwell $\mathrm{C}$ hardness, 63, material, SAE 52100 steel, run with SAE 52100 balls of varying hardnesses.

The life results for actual $\Delta \mathrm{H}$ increments of 0.5 are presented in figure 4 and are summarized in table III (p. 5); the data for actual $\Delta H$ increments of 1.0 are presented in figure 5 and are summarized in table IV (p. 6). The 10-percent lives for $\Delta \mathrm{H}$ increments of 0.5 and 1.0 are summarized in figure 6 . The peak life (405 million revolutions) for $\Delta \mathrm{H}$ increments of 0.5 occurs at an actual $\Delta \mathrm{H}$ between 1.5 and 2.0 points Rockwell $\mathrm{C}$ (fig. 6(a)). Additionally, this peak life is approximately four times the peak life (106 million revolutions) obtained at a nominal $\Delta \mathrm{H}$ of 2 for the initial bearing data presented in table II (p. 5). For actual $\Delta H$ increments of 1.0 (fig. 6(b)) the peak life is also increased but by a small amount relative to the nominal $\Delta H$ measurements $(129$ million revolutions compared with 106 million revolutions).

The data presented in figure 6(b) indicate that the bearings with an actual $\Delta H$ of between 1 and 2 points Rockwell $\mathrm{C}$ demonstrated a potential of four to five times greater fatigue life than could be achieved with bearings manufactured by normal methods.

The Weibull slopes summarized in tables III and IV for actual $\Delta H$ increments of 0.5 and 1.0, respectively, are plotted in figure 7. (The Weibull slope is a measure of the amount of scatter, that is, the greater the slope, the less the scatter. A slope of 1.1 is common for most bearing fatigue data.) Weibull slopes for the five-ball system data (table V) are plotted in figure 8. The upper test balls of the five-ball system (analogous to the inner race of the bearing) were of nominal Rockwell $\mathrm{C}$ hardnesses of 60,63 , and 65 and were run against lower test balls of varying hardnesses. Both the bearing and the 


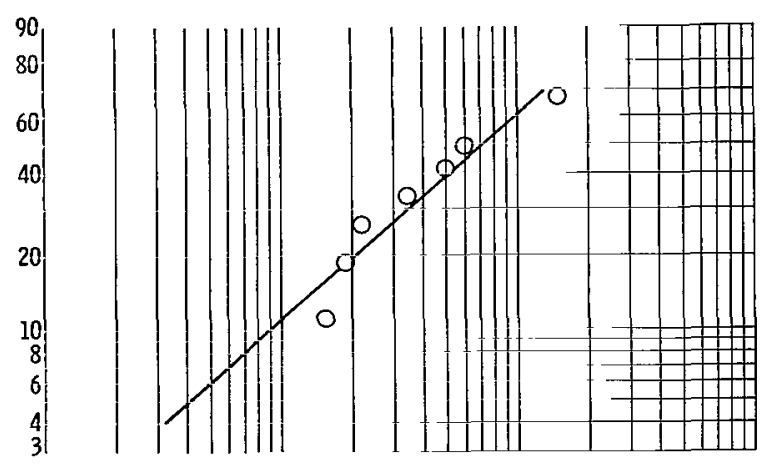

(a) $\Delta H$ between -1.5 and -1.0 Rockwell $C$.

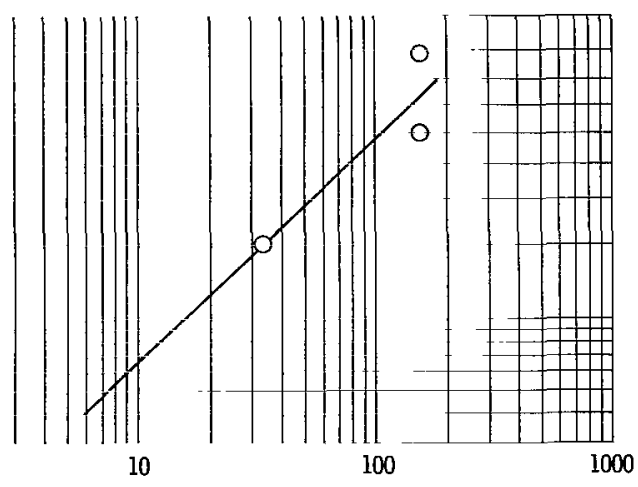

(c) $\Delta H$ between 0.5 and 1.0 Rockwell C.

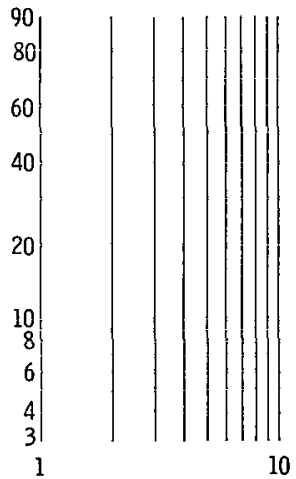

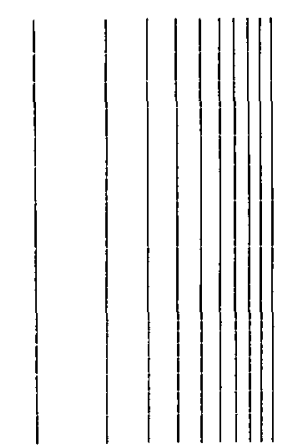

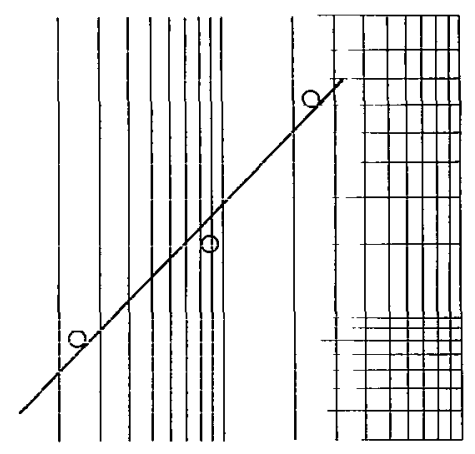

(b) $\Delta H$ between -1.0 and -0.5 Rockwell $C$.
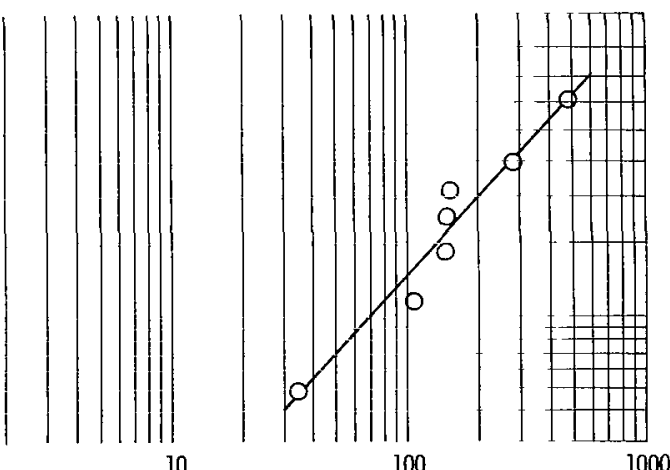

(d) $\Delta \mathrm{H}$ between 1.0 and 1.5 Rockwell C.

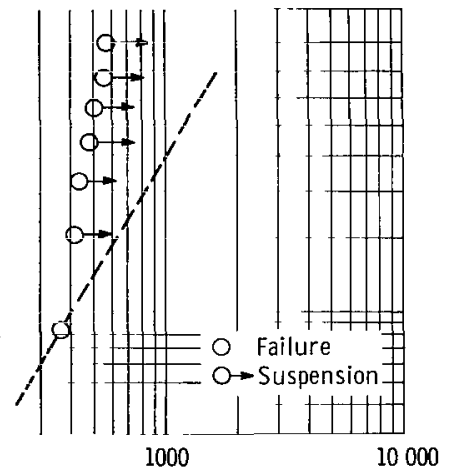

Bearing life, millions of inner-race revolutions

(e) $\Delta H$ between 1.5 and 2.0 Rockwell C.

Figure 4. - Rolling-contact fatigue life of 207-size deep-groove ball bearings for actual $\Delta \mathrm{H}$ (difference in Rockwell $\mathrm{C}$ hardness between balls and races) increments of 0.5 . Material, SAE 52100 steel for ball and races; radial load, 1320 pounds; speed, 2750 rpm; no heat added. 


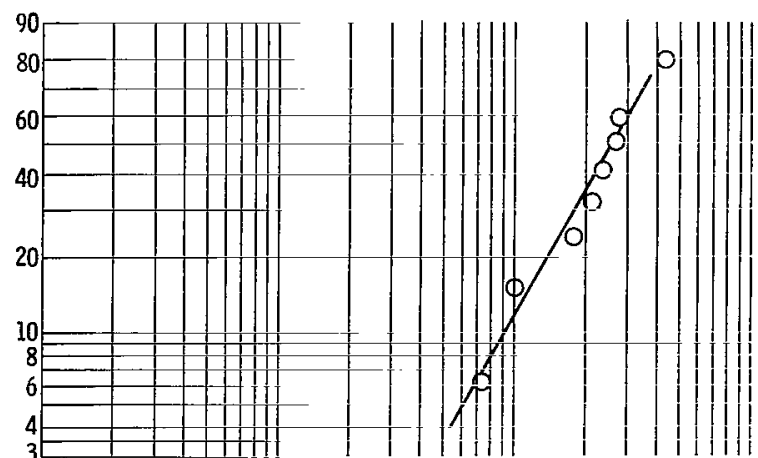

(f) $\Delta H$ between 2.0 and 2.5 Rockwell C.

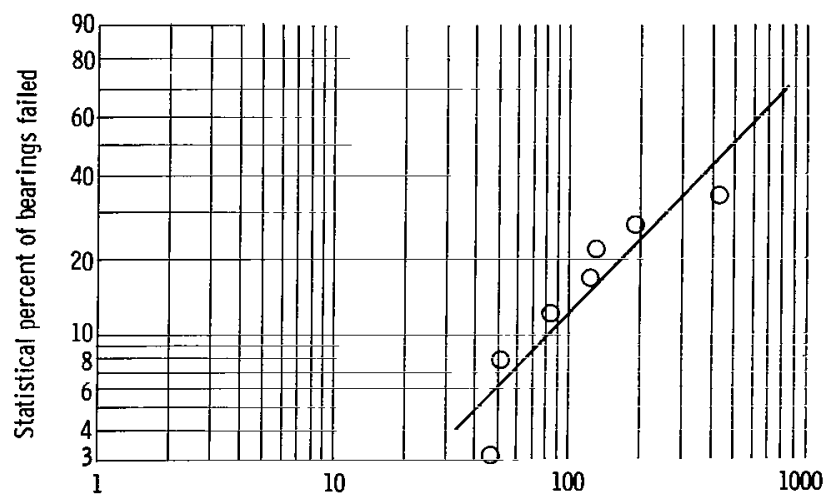

(h) $\Delta H$ between 3.0 and 3.5 Rockwell C.

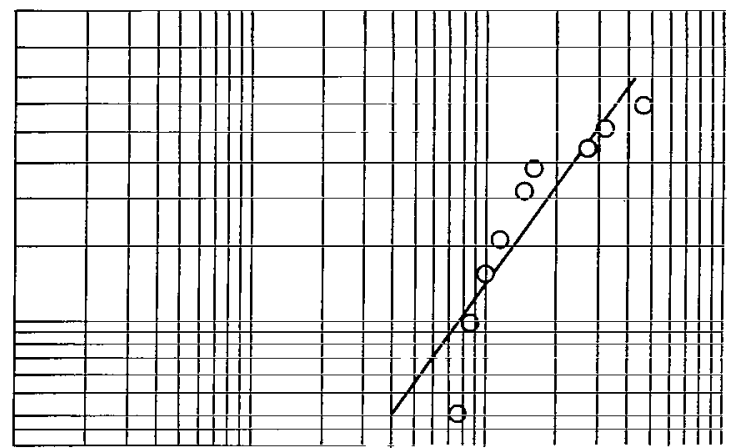

(g) $\Delta \mathrm{H}$ between 2.5 and 3.0 Rockwell C.

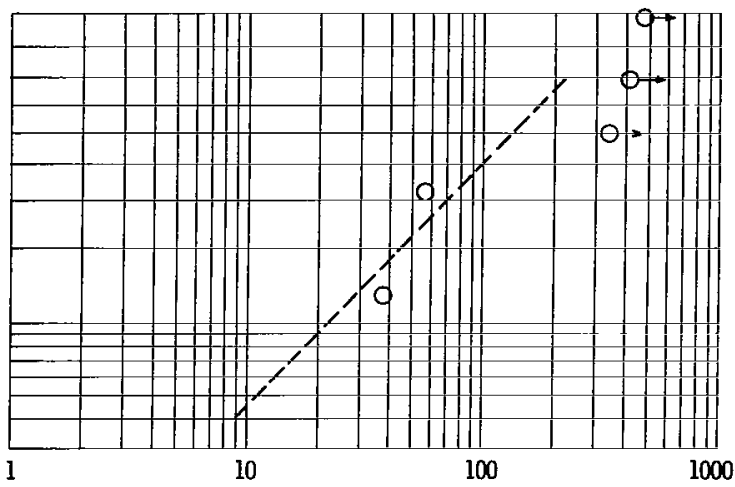

(i) $\Delta H$ between 3.5 and 4. 0 Rockwell C.

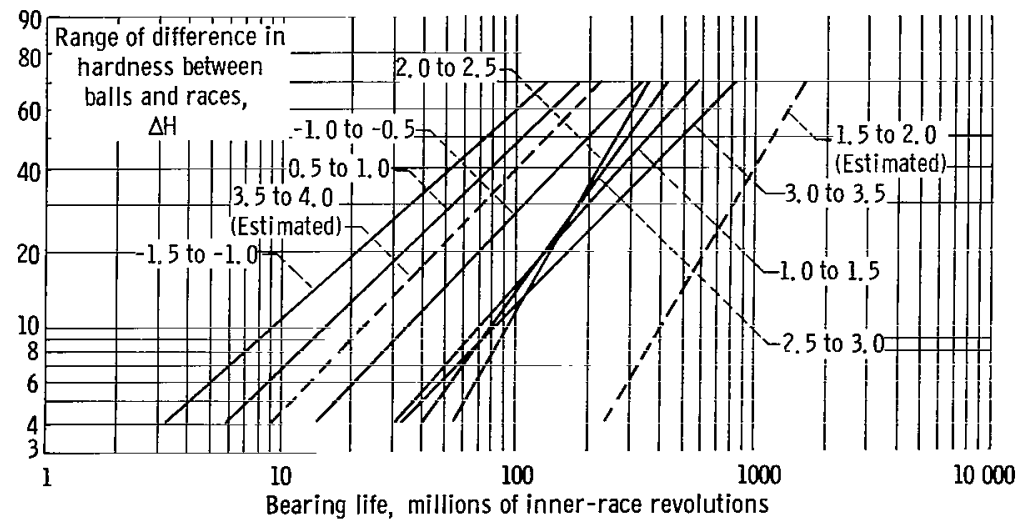

(j) Summary of fatigue lives.

Figure 4. - Concluded. 


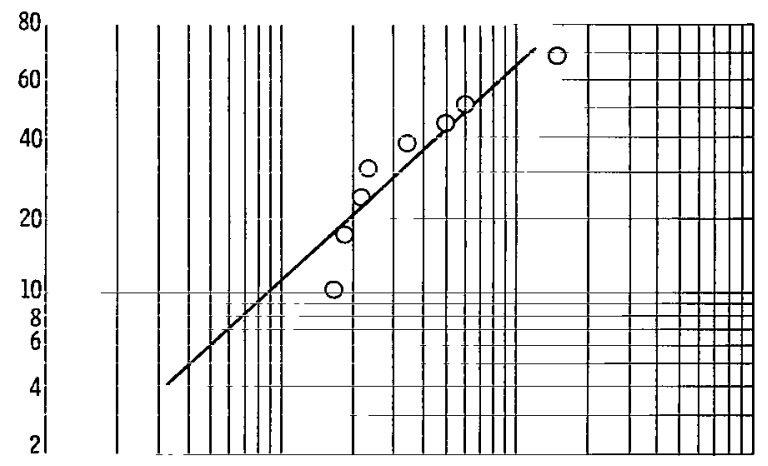

(a) $\Delta H$ between -2.0 and -1.0 Rockwell $C$.

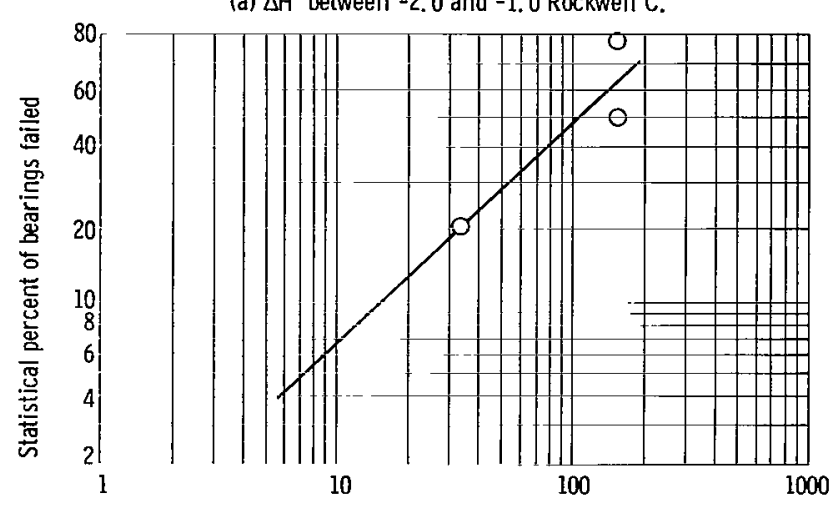

(c) $\Delta \mathrm{H}$ between 0 and 1.0 Rockwell $\mathrm{C}$.

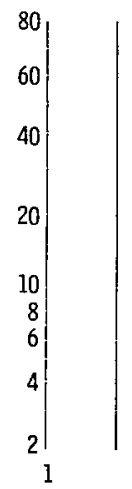

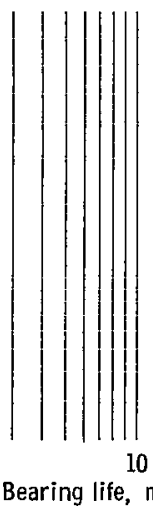

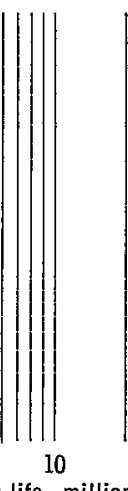

10

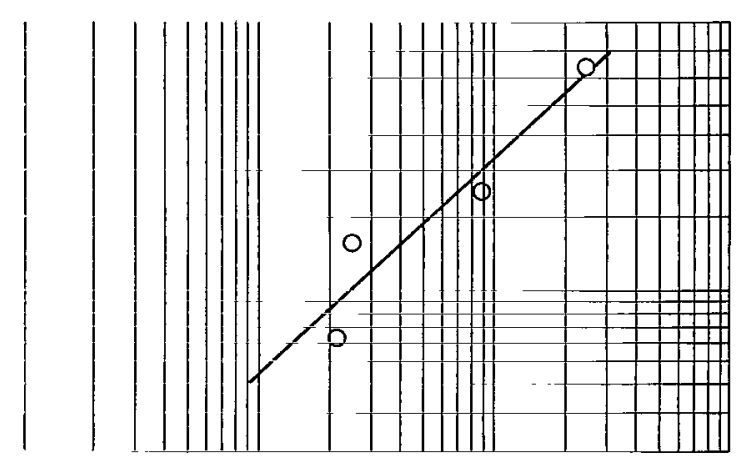

(b) $\Delta H$ between -1.0 and 0 Rockwell $C$.
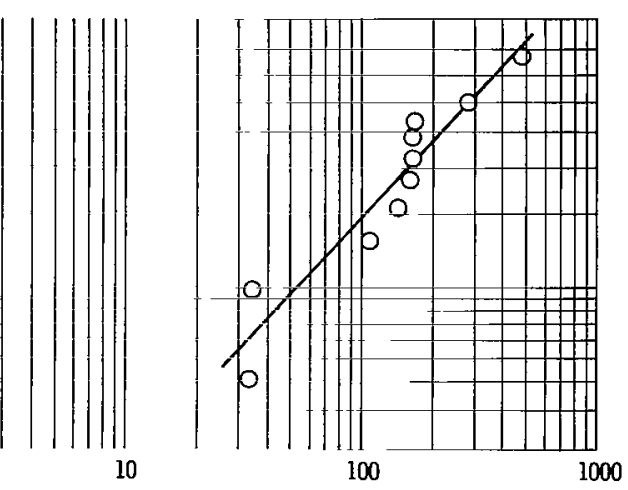

(d) $\triangle H$ between 0.5 and 1.5 Rockwell $C$.

(e) $\Delta H$ between 1.0 and 2,0 Rockwell $C$.

Figure 5. - Rolling-contact fatigue life of 207-size deep-groove ball bearings for actual $\Delta H$ (difference in Rockwell $\mathrm{C}$ hardness between balls and races) increments of 1.0. Material, SAE 52100 steel for balls and races; radial load, 1320 pounds; speed, 2750 rpm; no heat added. 


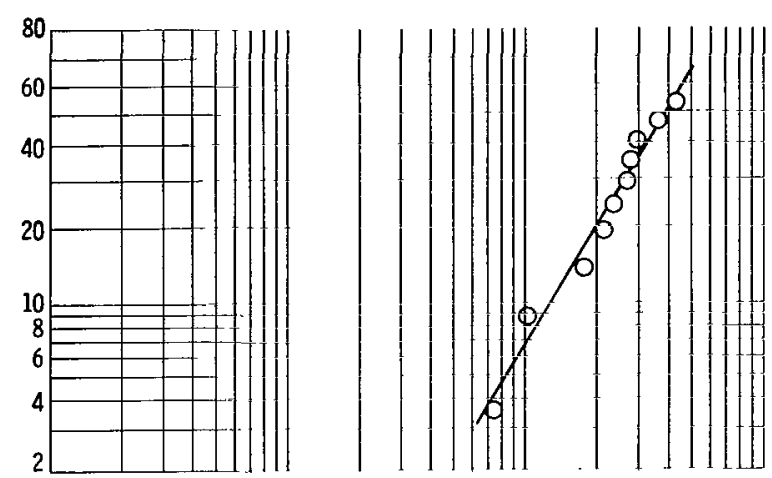

(f) $\Delta H$ between 1.5 and 2.5 Rockwell C.

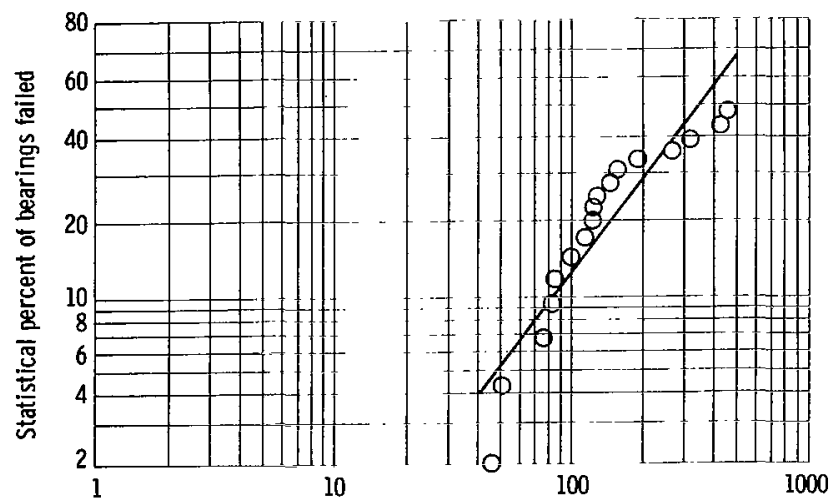

(h) $\Delta \mathrm{H}$ between 2.5 and 3.5 Rockwell C.

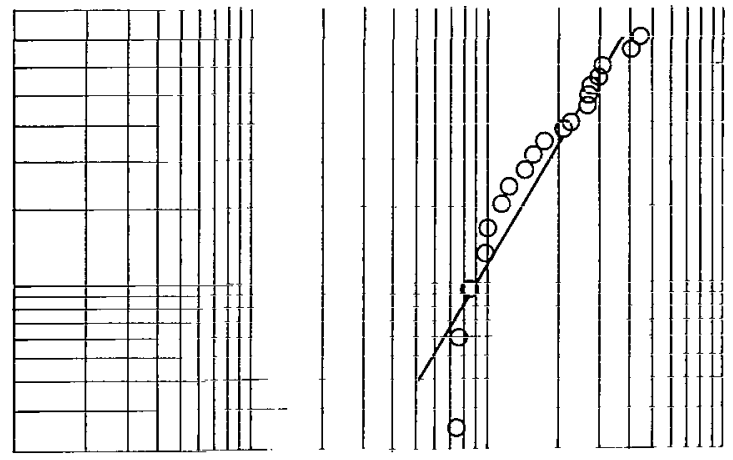

(g) $\Delta H$ between 2.0 and 3.0 Rockwell C.

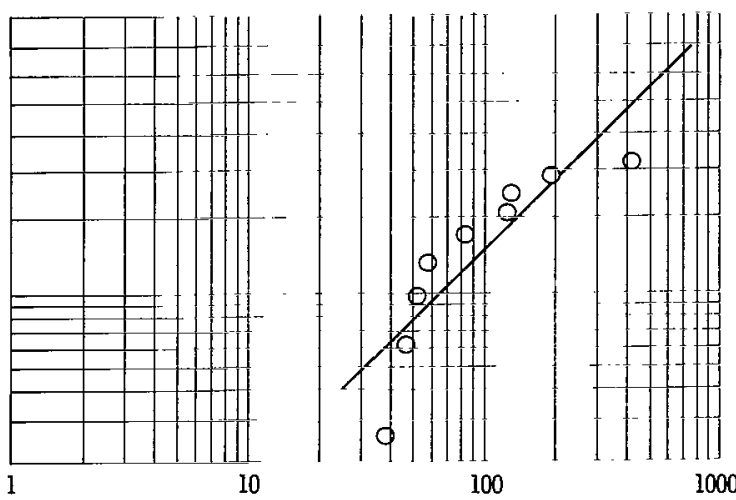

(i) $\triangle \mathrm{H}$ between 3.0 and 4.0 Rockwell C.

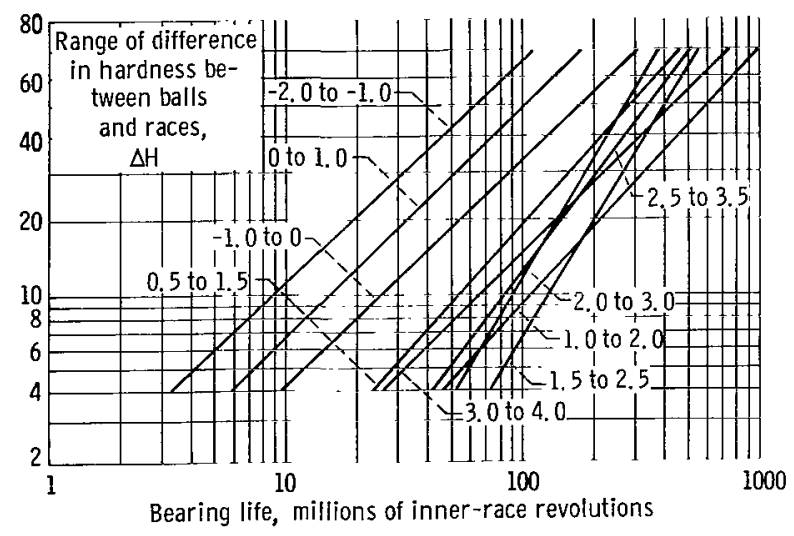

(j) Summary of fatigue lives.

Figure 5. - Concluded. 


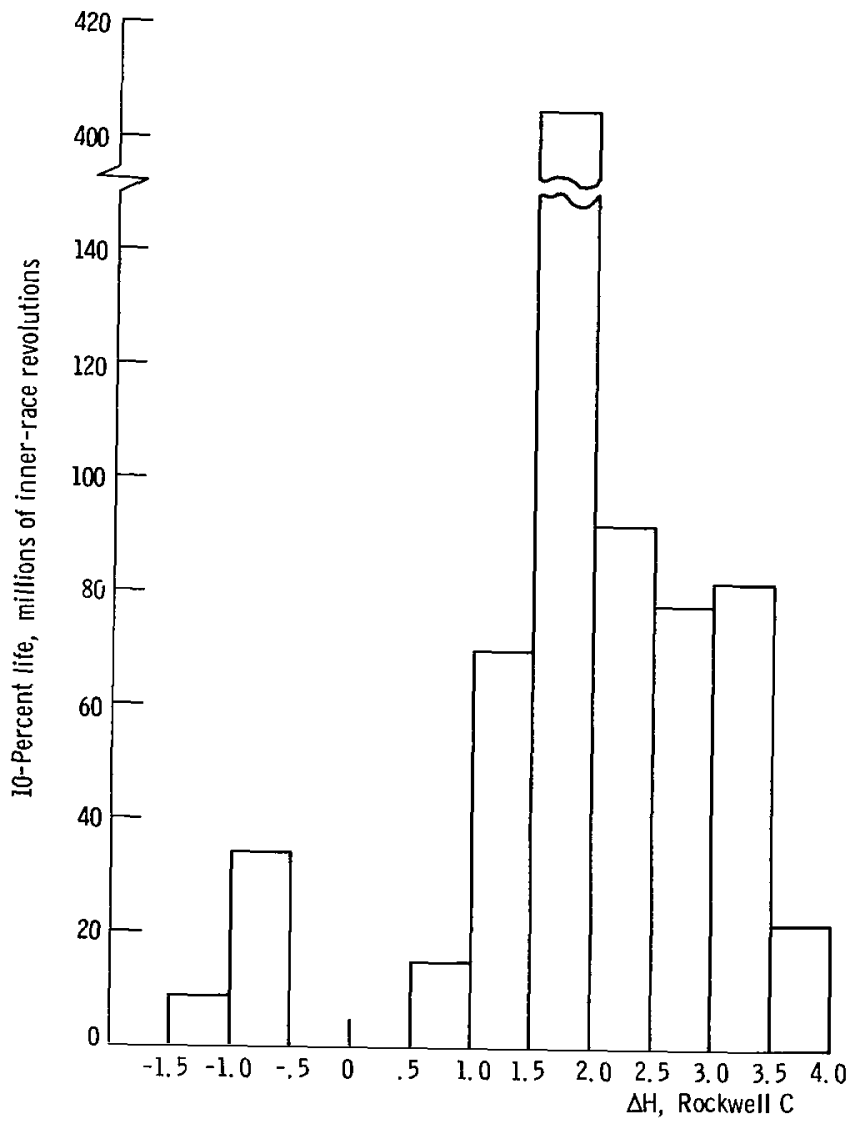

(a) Actual $\Delta H$ increment, 0.5 .

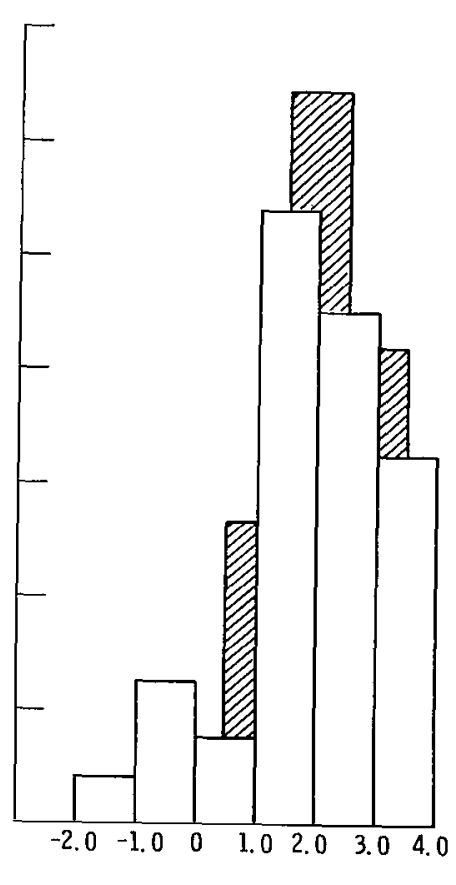

(b) Actual $\Delta H$ increment, 1.0.

Figure 6. - Ten-percent life as function of $\Delta H$ (difference in Rockwell $C$ hardness between balls and races) for 207-size deep-groove ball bearings. Material, SAE 52100 steel for balls and races; radial load, 1320 pounds; speed 2750 rpm; no heat added. 

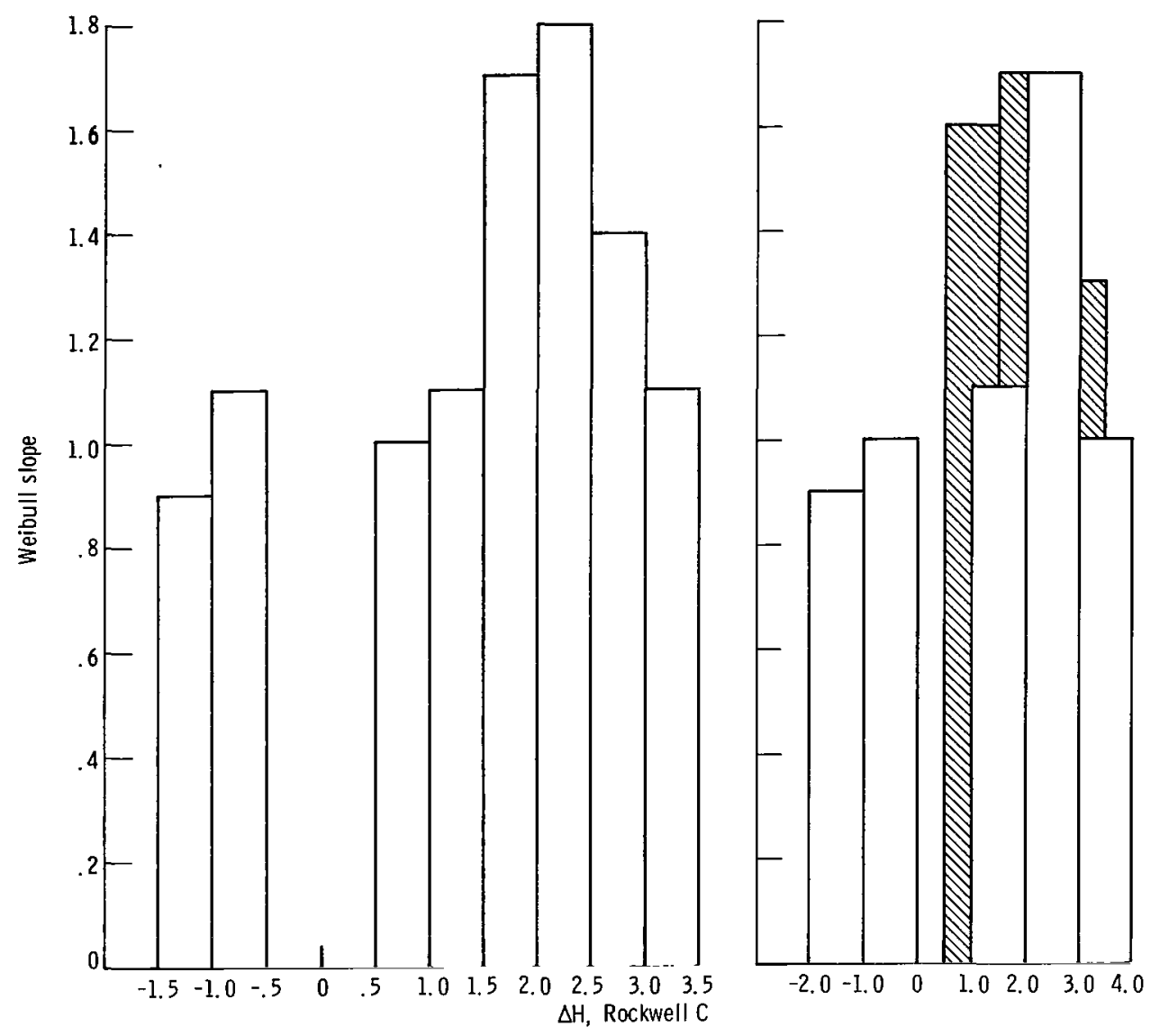

(a) Actual $\Delta H$ increment, 0.5 .

(b) Actual $\Delta \mathrm{H}$ increment, 1.0.

Figure 7. - Weibull slope as function of $\Delta \mathrm{H}$ (difference in Rockwell $\mathrm{C}$ hardness between balls and races) for 207-size deep-groove ball bearings. Material, SAE 52100 steel for balls and races; radial load, 1320 pounds; speed, $2750 \mathrm{rpm}$; no heat added. 


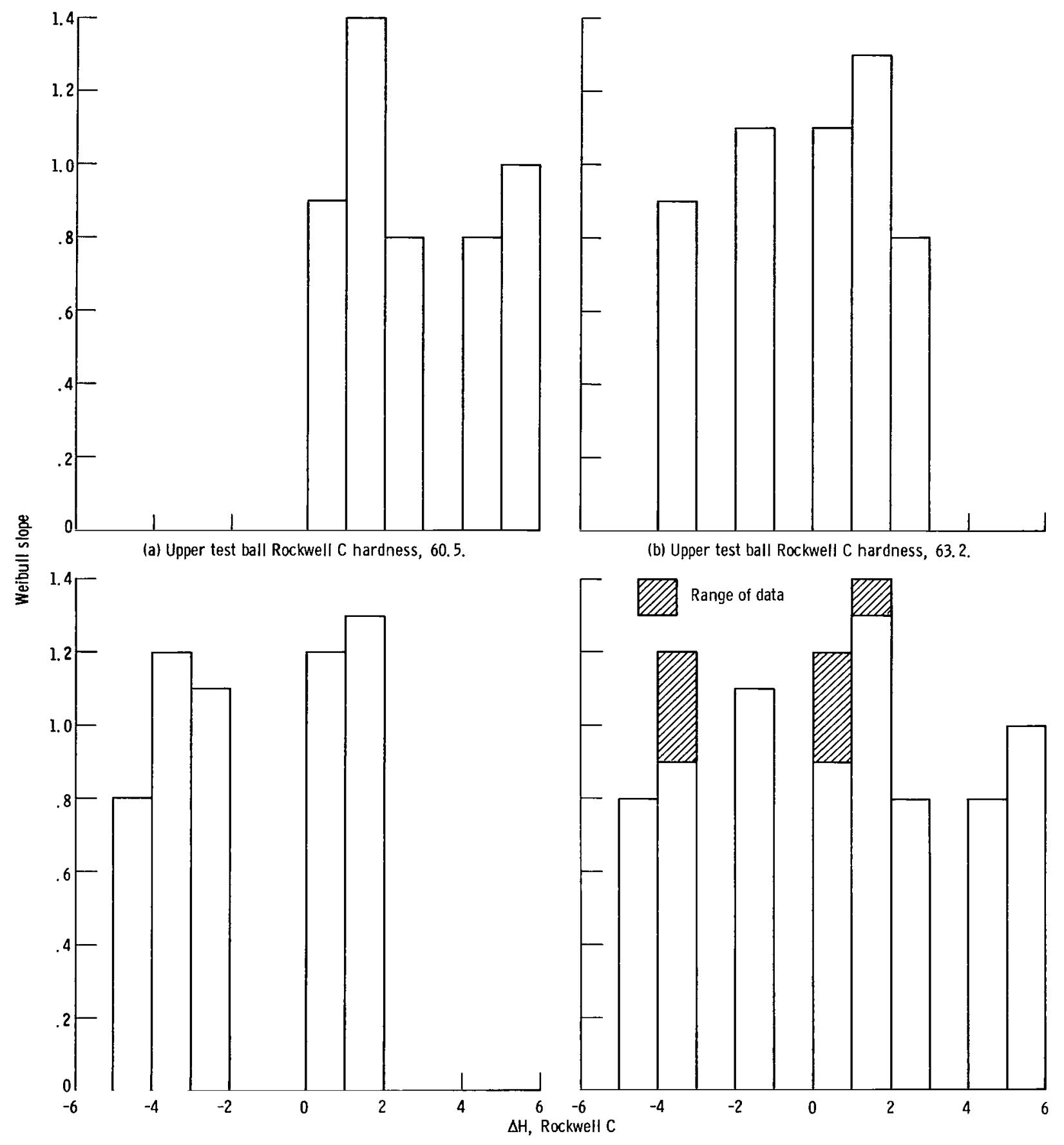

(c) Upper test ball Rockwell C hardness, 65.2.

(d) Summary of Weibull slopes.

Figure 8. - Weibull slope as function of $\Delta \mathrm{H}$ (difference in Rockwell $\mathrm{C}$ hardness between lower test balls and upper test ball) for upper and lower test balls of varying hardnesses. Five-ball fatigue tester; initial maximum Hertz stress, 800000 psi; system thrust load, 390 pounds; contact angle, $30^{\circ}$; room temperature; material, SAE 52100 steel (data from ref. 1 ). 
five-ball system data indicate that the amount of fatigue scatter is reduced as $\Delta H$ increases to a value of approximately 2 points Rockwell C. At this $\Delta \mathrm{H}$ value the slopes were 1.4 and 1.8 for the five-ball system and the bearings, respectively.

From these data it can be concluded that bearing fatigue life scatter is influenced by component hardness differences. These data indicate that if the optimum $\Delta H$ is properly selected, the probability of early failures in a group can be lessened.

\section{SUMMARY OF RESULTS}

Rolling-contact fatigue tests on 207-size deep-groove ball bearings were analyzed to determine the relation between actual component hardness differences on bearing fatigue life and scatter. These tests were conducted at a radial load of 1320 pounds, which produced maximum Hertz stresses of 352000 and 336000 psi at the inner and the outer races, respectively, at an inner-race speed of $2750 \mathrm{rpm}$, and with a highly purified naphthenic oil as the lubricant. The following results were obtained:

1. For actual $\Delta \mathrm{H}$ increments of 0.5 point Rockwell $\mathrm{C}$, the maximum fatigue life was obtained for a $\Delta \mathrm{H}$ range of 1.5 to 2.0 points Rockwell $\mathrm{C}$ where $\Delta \mathrm{H}$ is the difference between the actual hardness of the rolling elements in the bearing and the actual hardness of the race.

2. A relation is indicated between bearing fatigue life scatter and component hardness combinations. For both the full-scale bearings and the five-ball system, fatigue scatter decreased with increasing $\Delta \mathrm{H}$ until a minimum value was obtained at a $\Delta \mathrm{H}$ of approximately 2 points Rockwell $\mathrm{C}$.

3. The bearings having a $\Delta \mathrm{H}$ of between 1 and 2 points Rockwell $\mathrm{C}$ demonstrated a potential of four to five times greater fatigue life than could be achieved with bearings manufactured with normal methods.

Lewis Research Center,

National Aeronautics and Space Administration, Cleveland, Ohio, September 8, 1965. 


\section{REFERENCES}

1. Zaretsky, Erwin V.; Parker, Richard J.; and Anderson, William J. : Effect of Component Differential Hardness on Rolling-Contact Fatigue and Load Capacity. NASA TN D-2640, 1965.

2. Zaretsky, Erwin V.; Parker, Richard J.; Anderson, William J. ; and Miller, Steven T.: Effect of Component Differential Hardness on Residual Stress and Rolling-Contact Fatigue. NASA TN D-2664, 1965.

3. Zaretsky, E. V.; Parker, R. J.; and Anderson, W. J.: Component Hardness Differences and Their Effect on Bearing Fatigue. Paper No. 65-LUB-7, ASME, 1965.

4. Johnson, Leonard G. : The Statistical Treatment of Fatigue Experiments. Rept. No. GMR-202, General Motors Corp., Apr. 1959. 